\begin{tabular}{|c|l|}
\hline Title & $\begin{array}{l}\text { The Internal-Brooding A pparatus in the Bryozoan Genus Cauloramphus (Cheilostomata: Calloporidae) and Its Inferred } \\
\text { Homology to Ovicells }\end{array}$ \\
\hline Author(s) & Ostrovsky, Andrew N.; Dick, Matthew H.; Mawatari, Shunsuke F. \\
\hline Citation & $\begin{array}{l}\text { Zoological Science, 24(12), 1187-1196 } \\
\text { https://doi.org/10.2108/2s.24.1187 }\end{array}$ \\
\hline Issue Date & 2007-12 \\
\hline Doc URL & http://hdl.handle.net/2115/56381 \\
\hline Type & article \\
\hline File Information & zsi_24_1187.pdf \\
\hline
\end{tabular}

Instructions for use 


\title{
The Internal-Brooding Apparatus in the Bryozoan Genus Cauloramphus (Cheilostomata: Calloporidae) and Its Inferred Homology to Ovicells
}

\author{
Andrew N. Ostrovsky ${ }^{1 \dagger}$, Matthew H. Dick ${ }^{2 \star}$ and Shunsuke F. Mawatari ${ }^{3}$ \\ ${ }^{1}$ Department of Invertebrate Zoology, Faculty of Biology \& Soil Science, St. Petersburg State University, \\ Universitetskaja nab. 7/9, St. Petersburg 199034, Russia \\ ${ }^{2} \mathrm{COE}$ on Neo-Science of Natural History, Faculty of Science, \\ Hokkaido University, Sapporo 060-0810, Japan \\ ${ }^{3}$ Division of Natural History Sciences, Faculty of Science, \\ Hokkaido University, Sapporo 060-0810, Japan
}

\begin{abstract}
We studied by SEM the external morphology of the ooecium in eight bryozoans of the genus Cauloramphus Norman, 1903 (Cheilostomata, Calloporidae): C. spinifer, C. variegatus, C. magnus, C. multiavicularia, C. tortilis, C. cryptoarmatus, $C$. niger, and C. multispinosus, and by sectioning and light microscopy the anatomy of the brooding apparatus of $C$. spinifer, $C$. cryptoarmatus, and $C$. niger. These species all have a brood sac, formed by invagination of the non-calcified distal body wall of the maternal zooid, located in the distal half of the maternal (egg-producing) autozooid, and a vestigial, maternally budded kenozooidal ooecium. The brood sac comprises a main chamber and a long passage (neck) opening externally independently of the introvert. The non-calcified portion of the maternal distal wall between the neck and tip of the zooidal operculum is involved in closing and opening the brood sac, and contains both musculature and a reduced sclerite that suggest homology with the ooecial vesicle of a hyperstomial ovicell. We interpret the brooding apparatus in Cauloramphus as a highly modified form of cheilostome hyperstomial ovicell, as both types share 1) a brood chamber bounded by 2) the ooecium and 3) a component of the distal wall of the maternal zooid. We discuss Cauloramphus as a hypothetical penultimate stage in ovicell reduction in calloporid bryozoans. We suggest that the internal-brooding genus Gontarella, of uncertain taxonomic affinities, is actually a calloporid and represents the ultimate stage in which no trace of the ooecium remains. Internal brooding apparently evolved several times independently within the Calloporidae.
\end{abstract}

Key words: Bryozoa, Cauloramphus, ovicell, internal brooding, evolution, homology

\section{INTRODUCTION}

The majority of species of the bryozoan order Cheilostomata brood embryos in a specialized structure termed 'ovicell' by Busk (1852) and 'ooecium' by Hincks (1873). These initially synonymous terms reflected an old view that the brood chamber contains an ovary (see Levinsen [1909] for historical references). However, anatomical descriptions (Nitsche, 1869; Vigelius, 1884a, b; Calvet, 1900) soon made it clear that a single term was insufficient to describe the complexity of the cheilostome brooding apparatus. The problem was that 'ovicell' and 'ooecium' were used to refer to both the whole brooding apparatus and the externally visible covering of the brood chamber. While this loose usage did not affect taxonomists, it was unacceptable to anatomists.

\footnotetext{
* Corresponding author. Phone: +81-11-706-3524;

Fax : +81-11-746-0862;

E-mail: mhdick@mail.sci.hokudai.ac.jp

† Present address: Institut für Paläontologie, Geozentrum, Universität Wien, Althanstrasse 14, A-1090, Wien, Austria.

doi:10.2108/zsj.24.1187
}

Terminological changes made by Woollacott and Zimmer (1972) and supported by Ryland (1976), Ryland and Hayward (1977), Hayward and Ryland (1979), and Reed (1991) reflected the dual necessities of 1) separating the entire brooding apparatus (ovicell) from its parts, which include the protective hood (ooecium or ooecial outfold) generated either by the maternal (egg-producing) zooid or the distal zooid, the brooding cavity, and the closing device (ooecial vesicle or zooidal operculum), and 2) distinguishing between the contributions, in the majority of cases, of two zooids (maternal and daughter) to the structures of the brooding apparatus. Ryland and Hayward (1977), Hayward and Ryland (1979), Reed (1991), and Ostrovsky (1998) provided clear definitions. In this paper, we use the term 'ovicell' to refer to the entire brooding apparatus (including protective hood, brooding cavity, and closing device) and the term 'ooecium' to refer to the protective hood alone; however, we note that in quotes from previous authors, the terms may have been considered synonymous.

Separation of the terms 'ovicell' and 'ooecium' removes obvious contradictions that appear in some instances. An example is the commonly used phrase 'vestigial ovicell.' 
Only the protective fold (ooecium) can be vestigal, whereas the brooding chamber (brooding cavity) always remains well developed. If the term 'ovicell' is applied to the totality of the brooding apparatus, it cannot logically be referred to as vestigial in this case.

Usually cheilostome brooding structures are conspicuous, though they may be hidden to a greater or lesser extent by immersion in calcification associated with the frontal wall of the succeeding zooid. In some taxa, however, indications of the presence or absence of a brooding structure (indicated as either 'ovicell' or 'ooecium') have been ambiguous in the literature, as is the case with the genus Cauloramphus Norman, 1903 of the cheilostome family Calloporidae.

Norman (1903) mentioned nothing about ovicells, ooecia, embryos, or brooding in his original description of Cauloramphus. However, he designated C. spinifer (Johnston, 1832) as type species of the genus, and Hincks (1880, p. 149) had noted for this species (as Membranipora spinifera), "Ooecia shallow, smooth, with a rib across the front." This description may reflect an error in identification, since a rib on the ooecium is characteristic of other calloporid genera such as Callopora and Tegella. Bassler (1953, p. G160) simply noted, "Ovicells inconspicuous" in his generic diagnosis of Cauloramphus. In their monographs on British bryozoans, Ryland and Hayward (1977, p. 98) and Hayward and Ryland (1998, p. 172) included a reduced ovicell in their diagnosis of Cauloramphus. Their generic diagnosis was likely based strongly on $C$. spinifer, the only Cauloramphus they treated, for which they noted, "ovicell partly immersed, very small and depressed, not readily apparent but seen as a shallow, crescentic cap at the distal end of the autozooid; closed by the autozooidal operculum." Prenant and Bobin (1966, Fig. 70-IV) also included a description and drawing of the reduced ooecium in $C$. spinifer from France.

In fact, reports in Cauloramphus of structures related to brooding have been quite variable throughout the taxonomic literature. Hincks (1882, p. 250) indicated uncertainty in his original description of $C$. echinus by noting, "Ooecia (?)". Some species have been reported as having an inconspicuous, cap-like ovicell (e.g., Kluge, 1975; Mawatari and Mawatari, 1981; Dick and Ross, 1988). Despite previous reports of brood chambers in C. spinifer, Gostilovskaya (1978) noted for the White Sea population of this species that brood chambers were unknown. In other species, ovicells or ooecia have never been reported, e.g., $C$. cymbaeformis (Hincks, 1877); C. intermedius Kluge, 1962; C. pseudospinifer Androsova, 1958; C. disjunctus Canu and Bassler, 1929; and C. californiensis Soule, Soule, and Chaney, 1995.

We suspect that failure to report brooding structures in Cauloramphus is due both to the difficulty of seeing the external parts of these structures without scanning electron microscopy (SEM) and to authors simply failing to understand the condition of the ooecium, which is reduced. For example, Dick and Ross (1988) reported ovicells as "not observed" or "lacking" in three of the five Cauloramphus species they reported from Alaska; in C. magnus, they noted a vague connection between the internal brooding of embryos by zooids and a raised, crescentic lip distal to the orifice. As another example, Seo (2001, p. 225) noted in her original description of C. korensis, "Ovicells not seen," yet she inadvertently described the ooecium with "Distal to the orifice, transverse crescentic cap much raised above the level of mural rims," and her illustrations of this species (Seo, 2001, Fig. 1B, C, 2005, Figs. 32B, 33A) clearly show a fairly substantial ooecium.

Dick et al. (2005) and Grischenko et al. (2007) reported, but did not describe in detail, both ooecia and internal brooding in all seven species of Cauloramphus they treated between them, including five new species. This result suggests that an ooecium, reduced to a variable extent, and internal brooding are features common to all species of Cauloramphus.

In this study, we examined and compared the gross development and external morphology of the ooecium in eight species of Cauloramphus from the North Pacific. In addition, we examined by histological sectioning the anatomy of internal brooding in three of these species. On the basis of our results, we suggest hypotheses concerning the origin of reduced kenozooidal ooecia and internal brooding sacs through the modification of conventional ovicells, and the evolution of internal brooding in the cheilostome families Calloporidae and Flustridae.

\section{MATERIALS AND METHODS}

\section{Species examined}

The eight species included in this study were collected intertidally from the following localities:

Akkeshi Bay, Hokkaido, Japan, early June-early July 2004:

Cauloramphus spinifer (Johnston, 1832);

Cauloramphus magnus Dick and Ross, 1988;

Cauloramphus cryptoarmatus Grischenko, Dick, and Mawatari, 2007;

Cauloramphus niger Grischenko, Dick, and Mawatari, 2007;

Cauloramphus multispinosus Grischenko, Dick, and Mawatari, 2007.

Narrow Strait, Kodiak, Alaska, USA, September-December 1982: Cauloramphus variegatus (Hincks, 1881).

Ketchikan vicinity, Alaska, USA, 9-12 September 2003:

Cauloramphus multiavicularia Dick, Grischenko, and Mawatari, 2005;

Cauloramphus tortilis Dick, Grischenko, and Mawatari, 2005.

There has been much inconsistency in the literature regarding the suffixes used for species names in Cauloramphus. According to article 30.1.3 of the ICZN (1999), Cauloramphus must be treated as masculine in gender; hence, for species names other than those treated as nouns in apposition, we use the masculine form of the suffix.

\section{Microscopy}

Specimens of all species were collected alive and air-dried. Specimens were prepared for scanning electron microscopy (SEM) by immersion in a $7.5 \%$ sodium hypochlorite solution to remove the soft tissue, rinsed in distilled water, and air-dried. They were then coated with Pd-Pt in a Hitachi E-1030 sputter coater and observed with a Hitachi S-2380N scanning electron microscope at $15 \mathrm{kV}$ accelerating voltage. All images were stored electronically as TIFF files at a resolution of 200 pixels/cm with ImageCatcher software (Denshi Kongaku Kenkyusyo Co.).

For light microscopy, selected specimens of $C$. spinifer, $C$. cryptoarmatus, and C. niger were fixed in Bouin's fluid without acetic acid. These colonies were decalcified in a $2 \mathrm{M} \mathrm{HCl}$ solution, dehydrated in an ethanol series, embedded in TAAB 812 epoxy resin, sectioned ( $3 \mu \mathrm{m}$ thick) with a glass knife, and stained with Richardson's stain using standard methods. Richardson's stain 
(Richardson et al., 1960) contains methylene blue, azure II, and borax. In our preparations, methylene blue non-selectively stained cells of all types in soft tissues, whereas azure II selectively stained decalcified skeletal tissue.

\section{RESULTS}

All eight species studied have a strongly reduced ooecium evident externally (Figs. 1-3) and a sac in the coelomic cavity of the maternal zooid that functions for the brooding of embryos (Figs. 4, 5). The ooecium, located on the distal mural rim of the maternal (egg-producing) autozooid inside the semicircle of mural spines distal to the orifice, is a kenozooidal polymorph budded from the maternal zooid. Distally is a non-calcified outer membrane (ec in Fig. 4C, D) that we interpret as homologous to the distal portion of ectooecium (external ooecial wall) that is non-calcified in many conventional ooecia. Beneath this membrane is a space that we interpret as homologous with the coelomic lumen between the ectooecium and entooecium of conventional ooecia. We interpret the heavily calcified cap-like or crescentic structure (en in Fig. 4C, D) comprising the bulk of the ooecium along the distal rim of the zooidal opesia as homologous with the calcified entooecium (lower ooecial wall) of a conventional ovicell. In cleaned specimens, the border of the non-calcified ectooecium (removed in cleaning) is normally evident in both forming and completed ooecia (arrowheads in Fig. 2C, D). The basal part of the entooecium is fused with the distal wall of the maternal zooid (Figs. 4A-D, 5). In cleaned specimens of seven of the eight species examined, the surface of the entooecium is finely tuberculate, similar in texture to the zooidal cryptocyst (Figs.
2B, D, F, H, 3B-D). In C. spinifer it is smooth (Fig. 3A). The most proximal surface of the entooecium, facing the maternal zooid, is smooth in all species examined (e.g., Fig. 1A). Among the species examined, $C$. niger has the least reduced, most prominent ooecium, with a cap-like entooecium (Figs. 1D, 2H). In contrast, the entooecium is smooth and concave (cup-like) in C. spinifer (compare Figs. 1D and $2 \mathrm{H}$ with Figs. $1 \mathrm{~A}$ and $3 \mathrm{~A}$ ).

In a completed ooecium, the ooecial coelomic cavity (Figs. 4A-D, 5) consists of a larger upper part (oc in Fig. 4C, D) leading through a simple pore (ooecial pore; arrows in Figs. 2, 3) to a lower part comprising a narrow canal (Fig. 5). The canal connects to the visceral coelom of the maternal zooid by a single communication pore having a cuticular cincture and plugged by a specialized pore-cell complex (small arrows in Fig. 4C, D and Fig. 5). The ooecial pore (arrows, Figs. 1-3) is visible externally in specimens after removal of the overlying non-calcified ectooecium and associated cellular layers by cleaning with sodium hypochlorite (compare Figs. 2 and 3 with Figs. 4C, D and 5). This pore is situated at or near the midline and in sections was sometimes seen to be filled with non-specialized epithelial cells. The lower part of the ooecial coelom (canal) was often seen filled with a loose mass of peritoneal and outer-epithelial cells (Fig. 4D). These cells comprise the cellular layers between the coelom and outer wall in any bryozoan zooid; when part of the coelom becomes restricted in a narrow canal, these layers lining the canal become appressed as a more-or-less solid mass, with the coelomic cavity evident only as numerous intercellular spaces. The presence of a pore-cell complex clearly indicates that the ooecium is a
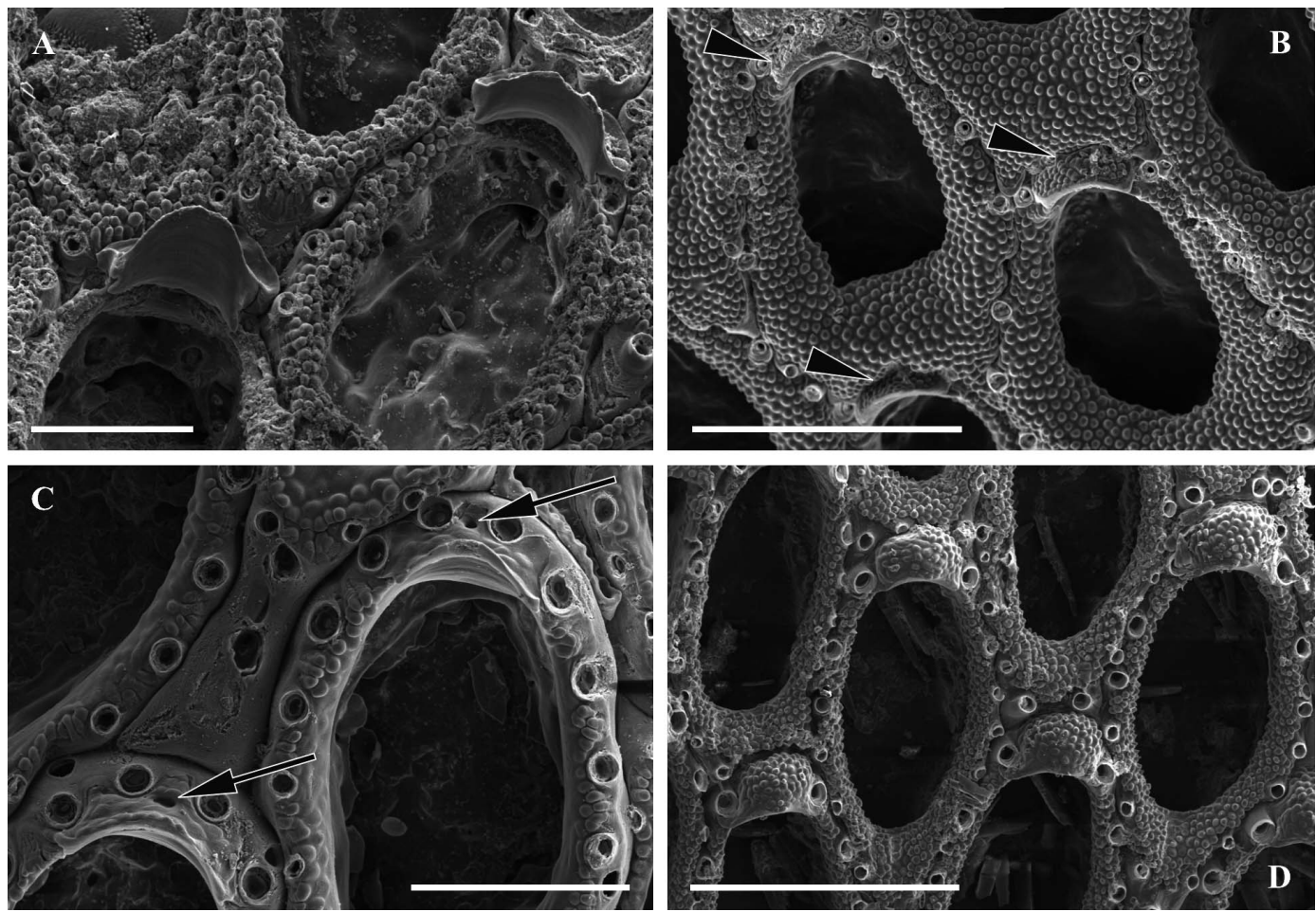

Fig. 1. Brooding autozooids with fully-formed vestigial ooecia (hypochlorite-cleaned specimens; SEM). (A) Cauloramphus spinifer; (B) C. cryptoarmatus; (C) C. multiavicularia; (D) C. niger. Arrowheads, ooecia; arrows, ooecial pores. Scale bars: A, C, $200 \mu \mathrm{m} ; \mathrm{B}, 400 \mu \mathrm{m}$; D, $500 \mu \mathrm{m}$. 

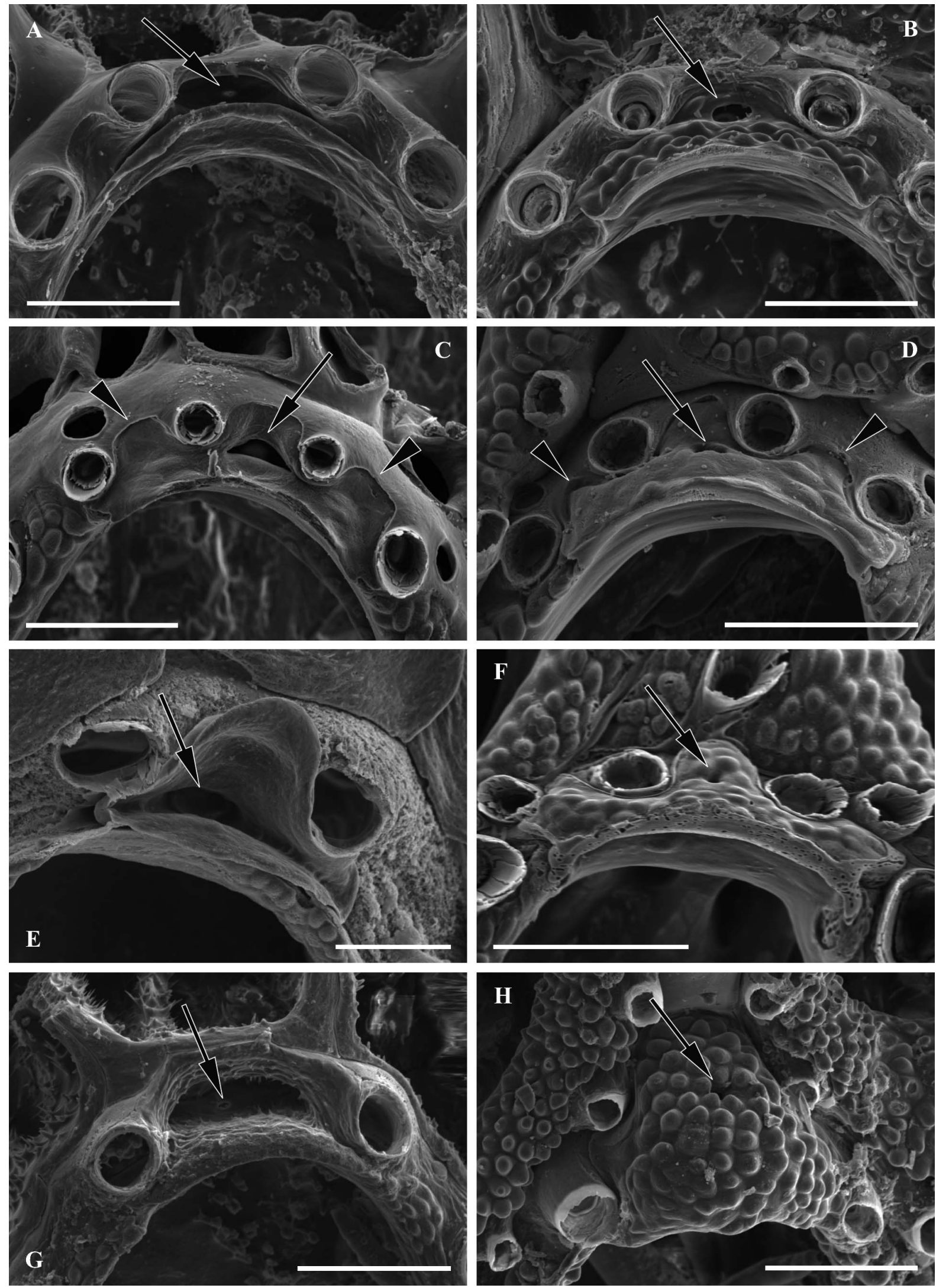

Fig. 2. Developing (left panels) and fully-formed (right panels) vestigial ooecia (hypochlorite-cleaned specimens; SEM). Arrows indicate ooecial pores; arrowheads in $C$ and $D$ point to the edge of the non-calcified ectooecium, which has been removed by cleaning. (A, B) Cauloramphus multispinosus; (C, D) C. multiavicularia; (E-F) C. tortilis; (G, H) C. niger. Scale bars: A-D, F-H, $100 \mu \mathrm{m}$; E, $50 \mu \mathrm{m}$. 

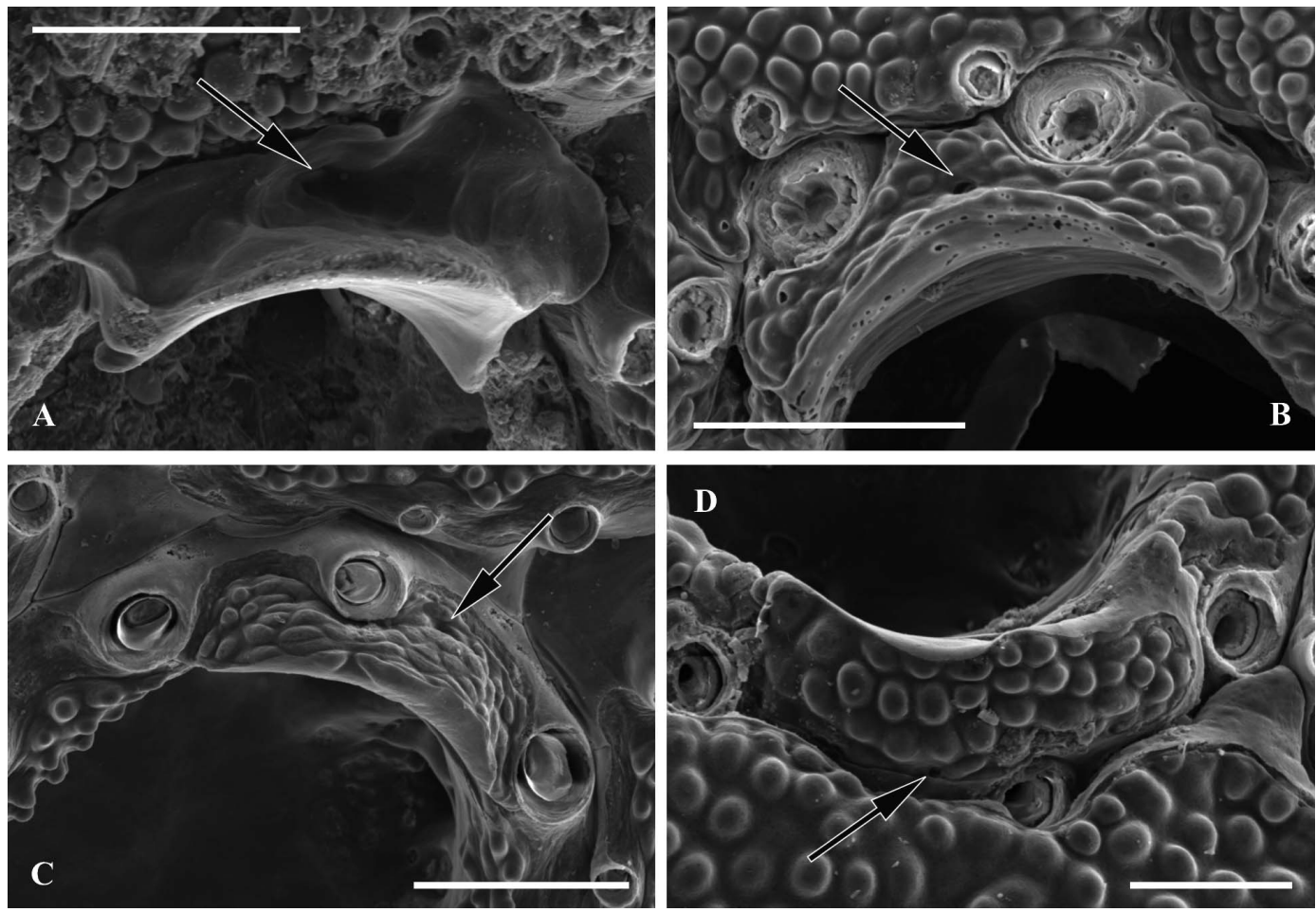

Fig. 3. Fully-formed vestigial ooecia. Arrows show ooecial pores cryptoarmatus. Scale bars: A-C, $100 \mu \mathrm{m}$; D, $50 \mu \mathrm{m}$.

daughter zooid budded from the maternal zooid; furthermore, since the ooecium is a highly modified zooid lacking a polypide and without either orifice or muscles, it is by definition a kenozooid (Hayward and Ryland, 1998).

The ooecium is budded by the maternal zooid; it lies above the distal mural rim of the maternal zooid and is functionally and morphologically separate from the distal autozooid (Fig. 5) that is also budded by the maternal zooid. Developing ooecia seen in young, peripheral zooids appear as a narrow groove or concavity that is actually the rudimentary ooecial coelom (Fig. 2A, C, E, G). During calcification, the entooecium thickens, the ooecial coelom is reduced, and the diameter of the communication canal decreases (compare Fig. 2A, C, E, G with Fig. 2B, D, F, H). Cauloramphus spinifer is atypical in that the completely formed ooecium as seen in cleaned specimens is characteristically a broad, rather deep cavity (Fig. $3 \mathrm{~A}$ ) distal to a raised, crescentic lip (Figs. 1A, 3A).

From the exterior, brooding zooids are distinguishable from non-brooding zooids by the presence of reduced ooecia and either oocytes or embryos visible through the semi-transparent frontal membrane (Fig. 4E). We observed embryos to be pink in C. spinifer (Fig. 4E) and up to $200 \times 120 \mu \mathrm{m}$ in size, and orange in C. cryptoarmatus and about $160 \times 90 \mu \mathrm{m}$ in size. Some were seen in sections to be surrounded by a fertilization envelope. In the species of Cauloramphus we examined, mature oocytes were positioned laterally either in the middle or proximal part of the zooid (asterisks, Fig. 4E); embryos were brooded inside the internal brood sac in the distal half of the maternal autozooid (Fig. 4E).

We observed the internal anatomy of brooding zooids for three species; although only $C$. spinifer and $C$. niger are illustrated in Fig. 4, C. cryptoarmatus showed similar structure, which is reflected in Fig. 5. The brood sac consists of a main chamber connecting with the exterior via a long, narrow neck. Although the neck appears cylindrical in longitudinal sections, it is actually a wide, dorsoventrally compressed passage. The neck opens to the exterior at the frontoproximal edge of the entooecium. The opening is located beneath the distal edge of the zooidal operculum when the latter is closed; it is also located near the vestibular opening, but is independent of the introvert (Figs. 4A-D, 5). The neck is closed distally by a fold of the distal-most part of the non-calcified frontal wall of the maternal zooid that is appressed against the adjoining entooecium, comparable with an ooecial vesicle in conventional ovicells (Fig. 4A, D; Fig. 5). In the lower base of the fold, there is a cuticular thickening that is presumably a reduced sclerite (in hyperstomial ovicells, the sclerite is a zone of thickened cuticle of the ooecial vesicle where the latter touches the ooecial fold). The sclerite is developed to different degrees in different brooding zooids within the same colony; sometimes it is slight (Fig. 4B, C). Two muscle bundles attach to the distal wall of the closing fold, one above and one below the sclerite; we were unable to trace the origins of these bundles. Numerous thin muscle bundles also attach to the basal wall of the neck of the brood sac (Figs. 4A-C, 5). Their origins are anchored onto the transverse, basal, and lateral cystid walls, and they presumably function to expand the neck during oviposition and larval release. We were not able to find muscles inserted on the sclerite.

The thin-walled brood sac and neck are an invagination of the non-calcified portion of the distal wall of the maternal 

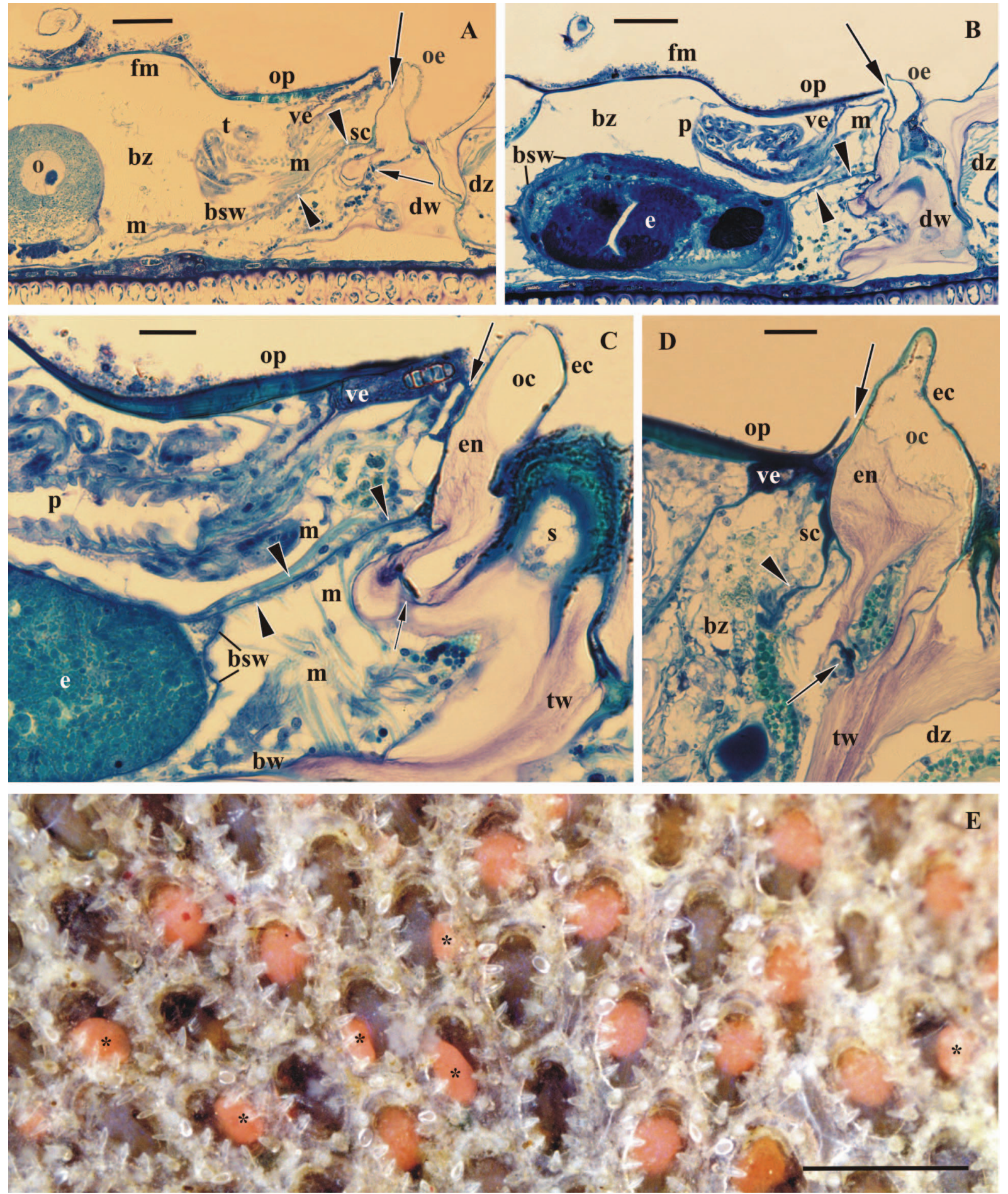

Fig. 4. Brooding zooids of Cauloramphus spinifer (A-C, E) and C. niger (D); light microscopy. (A) Longitudinal section of a zooid with an empty brood sac and a macrolecithal oocyte in the ovary. (B) Longitudinal section of a brooding zooid with an early embryo in the brood sac. (C) Enlargement of the distal end of a brooding zooid, showing part of the internal brood sac containing an embryo, the neck of the sac, and the vestigial kenozooidal ooecium. (D) Enlargement of the distal end of a brooding zooid, showing the neck, internal brood sac, and vestigial kenozooidal ooecium. In A-D: arrowheads, walls of the neck of the brood sac; larger arrows, entrance to the brood sac; smaller arrows, ooecial communication pore. (E) General view of living colony of C. spinifer. Asterisks indicate laterally positioned oocytes in different stages of development; embryos are located more centrally and toward the distal end of a zooid. Abbreviations: bsw, wall of the brood sac; bz, brooding zooid; bw, basal wall; dw, distal wall of brooding zooid; dz, distal zooid; e, embryo; ec, ectooecium; en, entooecium; fm, frontal membrane; m, muscular bundles of the brooding sac and closing fold of the non-calcified frontal wall of the maternal zooid; o, oocyte; oc, ooecial coelom; oe, ooecium; op, operculum; p, polypide; s, spine; sc, sclerite; t, tentacles; tw, transversal wall; ve, vestibulum. Scale bars: A-B, $50 \mu \mathrm{m}$; C-D, 20 $\mu \mathrm{m} ; \mathrm{E}, 500 \mu \mathrm{m}$ 


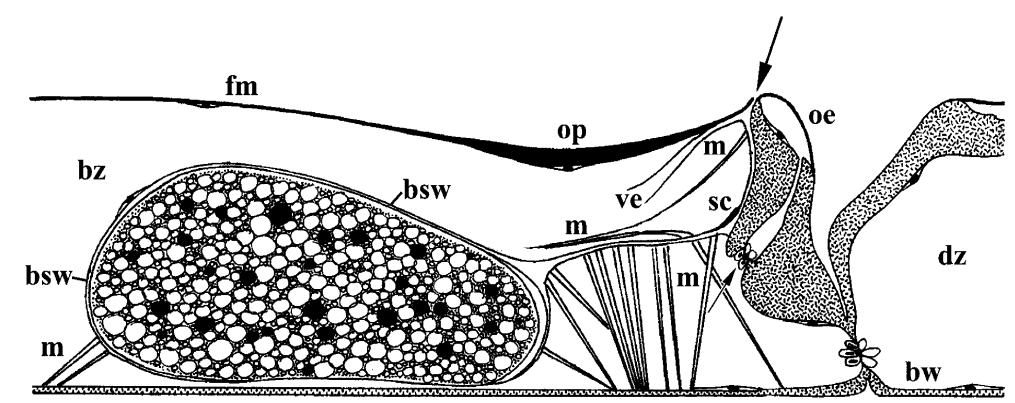

Fig. 5. Schematic longitudinal section through a brooding zooid of Cauloramphus spinifer with an early embryo in the internal brood sac. Larger arrow, entrance to the brood sac; smaller arrow, ooecial communication pore. Abbreviations: bsw, wall of the brood sac; bz, brooding zooid; bw, basal wall; dz, distal zooid; fm, frontal membrane; $m$, muscular bundles of the brood sac and closing fold of the non-calcified frontal wall of the maternal zooid; oe, ooecium; op, operculum; sc, sclerite; ve, vestibulum.

zooid. The brood sac is easily deformed; when not containing an embryo, it is completely flattened, positioned just above the basal wall, and extends for up to half the length of the cystid (Fig. 4A). Its wall consists of a thin cuticle and underlying epidermal and peritoneal epithelia. Several groups of muscles insert on the basal and lateral walls of both the distal and proximal parts the main chamber of the sac. Their origins are on the basal wall and basal part of the lateral cystid walls (Fig. 4A; Fig. 5). These muscles possibly serve to extend the brood sac during larval release, and perhaps during oviposition as well.

Polypide recycling can occur during brooding. The polypide degenerates some time after oviposition, and a new one begins to grow.

\section{DISCUSSION}

\section{Kenozooidal ooecia among cheilostomes}

In most cheilostomes that have been studied, the ooecium is an outfold of the distal autozooid (discussed in Ostrovsky, 1998); ooecia with direct pore connections to the maternal zooid (that is, maternally budded) appear to be rare. A maternally derived ooecium has been reported in the cribrimorph cheilostome Cribrilina annulata (Fabricius, 1780) (Levinsen, 1909; Ostrovsky, 1998). In this species, the ooecium is much larger than in Cauloramphus, covering the whole distal part of the maternal zooid. In addition, Winston and Håkansson (1986) illustrated a knob-like and obviously kenozooidal ooecium for Cymulopora uniserialis. At present, these two examples and Cauloramphus should be considered as exceptions among cheilostomes, and are the only cases that support Silén's $(1945,1977)$ general model of derivation of the ooecium from the maternal zooid.

The interpretation by Woollacott and Zimmer (1972) of the ooecium of Bugula neritina (Bugulidae) as a kenozooidal polymorph is not correct, since there is no pore-cell complex between the ooecial cavity and the visceral coelom of the distal autozooid; for details and discussion, see Ostrovsky and Schäfer (2003). It is possible that the unusual, complex ooecia of Scrupariidae and Alysidiidae also consist of two (Scruparia, Brettiopsis, Alysidium) to eight (Catenicula) kenozooids budded from the maternal zooid (Levinsen, 1909; Hyman, 1959; Mawatari, 1973; Hayward, 1995), but this needs checking. Furthermore, the brood chambers in these two families could have evolved independently from those of other cheilostomes (Osburn, 1950; Taylor, 1988).

\section{The internal-brooding apparatus as a highly modified ovicell}

Hyperstomial ovicells are the most common type of brood chamber in cheilostome bryozoans and consist of the following elements: 1) the ooecium, a double-walled, often hemispherical outgrowth, produced either by the maternal (egg-producing) zooid or the distal auto- or kenozooid, containing an enclosed coelomic lumen that connects with the zooid of origin through one or more pores; 2) a component of non-calcified distal wall from the maternal zooid, often in the form of an ooecial vesicle (=ooecial plug), and 3) a brood chamber (brooding cavity) bounded by the ooecial and maternal-wall components (Ryland, 1976; Ryland and Hayward, 1977; Reed, 1991; Ostrovsky, 1998; Ostrovsky et al., 2003, 2006). The brooding apparatus in Cauloramphus contains all these elements (all maternally derived) and thus shows homology with cheilostome hyperstomial ovicells, though highly modified in form. The ooecium in Cauloramphus is kenozooidal and reduced, ranging in extent from a moderately reduced hemispherical cap in $C$. niger to a highly reduced, vestigial ooecium lying on the distal opesial rim, as in C. spinifer. In Cauloramphus, the component of non-calcified distal wall from the maternal zooid has shifted from the more elevated position it would occupy at the proximal side of a hyperstomial ooecial brood chamber to a position beneath the distal end of the zooidal operculum. The sclerite correspondingly is shifted basally and reduced, and has lost its musculature. Nonetheless, even in this position, the distal maternal-wall component and associated muscles are still involved in the closing and opening of the internal brood sac, performing the same function they do, for example, in the ooecial vesicle of a hyperstomial ovicell.

The internal brood sac is a deep invagination of the distal wall of the maternal zooid. Though the brood sac lies internal to the maternal zooid, its cavity is topologically external, just as is the brood chamber of a hyperstomial ovicell. That is, the inner surface of the invaginated brood sac is continuous with and corresponds to the outer surface of the non-calcified distal wall of the maternal zooid. The external opening of the 'neck' abuts the proximal surface of the kenozooidal ooecium. The brood sac is thus bounded by the reduced ooecium (ooecial component) and invaginated brood pouch (maternal-wall component), similarly to a hyperstomial ovicell. Nonetheless, although internal brooding in Cauloramphus involves structures homologous to those 
comprising the typical cheilostome hyperstomial ovicell, internal brooding in this and some other cheilostome genera must be regarded as an evolutionary novelty. That is, the deep invagination in the non-calcified portion of the maternal distal wall to produce the brood sac is a novel structure not present in hyperstomial ovicells.

\section{Evolution of internal brooding in Calloporidae}

Ostrovsky et al. (2006) argued and provided supporting evidence that internal brooding has evolved independently in several different neocheilostome lineages. They also postulated hypothetical steps that might have been involved in the evolutionary transition from a hyperstomial ovicell to an internal brood sac in cheilostomes. These steps are 1) reduction of the ooecium and proximal displacement of the brooding cavity, followed by 2 ) reduction of the sclerite of the ooecial vesicle and the sclerite musculature, further proximal displacement of the main chamber, and consequent lengthening of the neck of the brood sac. Though most calloporids have hyperstomial ovicells, it may be that internal brooding evolved independently multiple times even within this neocheilostome group.

The genus Cauloramphus exemplifies a late stage in the evolution of internal brooding in the Calloporidae, with the vestigial kenozooidal ooecium representing the nearly complete reduction of the ooecium-forming (distal) zooid and its ooecial outfold (for details and discussion, see Bishop and Househam, 1987; Ostrovsky, 1998). In most cheilostomes, the ooecium is formed from the zooid distal to the maternal (egg-producing) zooid (Ostrovsky, 1998). This distal zooid can be either an autozooid, with a functional feeding polypide (the majority of cases), or a kenozooid that lacks a feeding polypide. In a transition series in which a distal, ooecium-forming kenozooid becomes increasingly reduced, a point is reached where this distal zooid no longer has interzooidal connections with any adjacent zooids other than the proximal (maternal) zooid, which is the case in Cauloramphus. In evolutionary derivation, what we are calling the kenozooidal ooecium is equivalent to both the formerly distal zooid (lower part) and its ooecial outfold (upper part). In Cauloramphus, the maternal zooid is also connected to next autozooid in series; an ability to contribute to budding the next autozooid in a column is necessary unless growth of the colony is to stop with every zooid that produces a kenozooidal ooecium. This ability to contribute to the next distal autozooid in addition to budding the ooecial kenozooid requires nothing more than establishment of a new pore chamber, which should be an evolutionarily easily effected change.

Cauloramphus may not represent the ultimate stage in the evolution of internal brooding in calloporids. The internal brood sac in the genus Gontarella (Grischenko et al., 2002; Ostrovsky et al., 2006) is quite similar to that in Cauloramphus, in terms of the structure of the sac, the positions of its attached muscle bands, and the long neck. These similarities, along with the simple zooidal morphology and encrusting growth form of Gontarella, suggest that Gontarella might belong in the Calloporidae rather than in the Flustridae as Ostrovsky et al. (2006) previously suggested. This is supported by the observation (Ostrovsky et al., 2006) that the internal brood sacs of Cauloramphus and
Gontarella differ from those in representative species of the flustrid genera Nematoflustra and Biflustra, which have a different muscle arrangement and a shorter neck. In Gontarella, there is no trace of a kenozooidal ooecium, nor of a vestigial sclerite of the ooecial vescicle. Thus, if Gontarella is indeed a calloporid, it represents a stage of ovicell reduction and modification beyond that of Cauloramphus, and perhaps the ultimate stage in this evolutionary series.

The question arises as to whether earlier stages are evident in the Calloporidae with regard to the reduction of the distal ovicell-forming autozooid and ovicell leading to the morphology seen in Cauloramphus and Cymulopora. A welldeveloped kenozooidal ooecium directly budded from the maternal zooid, such as that seen in Cribrilina annulata discussed above, possibly exemplifies an intermediate morphology; however, this ovicell type has not been reported in any calloporid, whereas terminal ooecia formed by a reduced distal kenozooid are widespread among calloporids.

Another theoretical possibility for the evolution of an internal sac in calloporids is by modification of an immersed ovicell, with the vestigial ooecium (outfold) formed by the distal zooid. Such immersed ovicells with vestigial ooecia are well known among Calloporidae, for instance in the genera Crassimarginatella (Hastings, 1945, 1964; Cook, 1968; Winston, 1984; Tilbrook et al., 2001) and Cranosina (Osburn, 1950; Chimonides and Cook, 1994). Immersed ovicells in calloporids differ from the endozooidal ovicells of flustrids, since their brooding cavity is immersed in the distal part of the maternal zooid, rather than in the proximal part of the daughter zooid as in flustrids (Ostrovsky, unpublished data). Of particular interest are Aplousina filum Jullien and Calvet, 1903 and A. gigantea Canu and Bassler, 1927 (see Cook, 1968), which are quite similar to Gontarella in zooid shape and size but possess immersed ovicells with small, cap-like ooecia. We suggest that an ovicell of this type could transform to an internal brood sac by complete reduction of the ooecium (and, possibly, the sclerite of the ooecial vesicle). Further proximal displacement could lead to formation of an internal sac with a prominent neck, as seen in Gontarella.

Relevant to this discussion is the species Septentriopora karasi Kuklinski and Taylor, 2006. All other known species of the calloporid genus Septentriopora have subimmersed ovicells with small (but not vestigial) ooecia formed by the distal autozooid. In contrast, supposedly brooding zooids of S. karasi have in place of the conventional ooecium a small kenozooid. Kuklinski and Taylor (2006) referred to this kenozooid as a "vestigial ovicell," noting that it originates from the two proximolateral corners of the distal zooid, with which it communicates by multiporous septula. However, this interpretation is questionable, since no other cheilostomes with this type of ooecium are presently known (see above). The vast majority of Cheilostomata possess ooecia that are outfolds of the distal zooid. These ooecia have no septula or pore-cell complexes; rather, their coelomic cavity is connected with the visceral coelom of the distal zooid via slits or simple pores. We speculate that $S$. karasi is an internal brooder that lost its ooecia in a similar manner to Gontarella. However, it has acquired a kenozooid that positionally substitutes the ooecium.

Although in the course of this study we directly observed 
embryos in only two of the species examined (C. spinifer and $C$. cryptoarmatus), internally brooded embryos have been reported for all the species examined (Dick and Ross, 1988; Dick et al., 2005; Grischenko et al., 2007). These data coupled with our observation of ooecia in the eight species studied strongly suggest that a reduced, maternally produced kenozooidal ooecium and internal brood sac are characters common to all species of Cauloramphus and should thus be appended as diagnostic characters for this genus. As for the Cauloramphus species for which neither ooecia nor embryos have been reported (see Introduction), we suggest that these reproductive features have simply not yet been found due to lack of detailed observation.

A number of interesting questions remain. It is not yet known, for example, whether internal brooding is a synapomorphy for Cauloramphus, as opposed to a plesiomorphic character in the common ancestor of Cauloramphus and its sister group (also unknown), or in an even more distant ancestor. In a similar context, verification that internal brooding arose independently multiple times in Calloporidae will require a reliable (i.e., molecular) phylogeny of this family.

Another problem is exactly how or in response to what stimuli the fertilized egg travels from the coelom of the maternal zooid to the external brood sac. Presumably, oviposition is carried out in a manner similar to that in other brooding cheilostomes, in which a highly plastic oocyte squeezes through the supraneural coelomopore and enters the opening of the brood cavity (Gerwerzhagen, 1913; Silén, 1945; Corrêa, 1948; Nielsen, 1981; Dyrynda and King, 1983).

Finally, why internal brooding evolved from hyperstomial brooding repeatedly both among and within neocheilostome lineages is an open question. Ostrovsky et al. (2006) proposed several hypotheses (not mutually exclusive) to explain this transition: (1) reduction of ooecia could conserve energy for somatic growth and reproduction; (2) internal brooding cavities may be more spacious than ovicells, allowing the brooding of larger larvae; and (3) internal brooding may be an evolutionary response to the evolution of predators that feed on embryos held in ovicells. In any case, the numerous internal brooders known among different cheilostome families shows that the internalization of brooding is a novelty that allows them to successfully compete with relatives possessing ooecia in the form of prominent protective hoods. Ultimately, the selective forces driving this transition will need to be empirically investigated.

\section{ACKNOWLEDGMENTS}

We thank Dr. Andrei V. Grischenko, Perm State University, for collecting some of the material studied and for very useful discussions; the staff of the Akkeshi Marine Biological Station, Hokkaido University, for technical support during collecting; Dr. Yoshinobu Nodasaka, School of Dentistry, Hokkaido University, for assistance with microscopy; Dr. John Ryland, University of Wales, Swansea, for advice on the correct suffixes for species names in Cauloramphus; and two anonymous reviewers whose comments substantially improved the manuscript. This research was supported by the $21 \mathrm{st}$ Century Center of Excellence (COE) Program on "Neo-Science of Natural History" at Hokkaido University, financed by the Ministry of Education, Culture, Sports, Science, and Technology, Japan; FWF grant (Austria) P19337-B17 and RFBR grant (Russia) 07-0400928a to ANO; and a Grant-in-Aid for Scientific Research
(17570070) from the Japan Society for the Promotion of Science to MHD and SFM.

\section{REFERENCES}

Androsova El (1958) Bryozoa of the order Cheilostomata of the northern part of the Sea of Japan. Issledovaniya dal'nevostochnix Morei SSSR (Explorations of the Far Eastern Seas of the USSR) 5: 90-204 (In Russian)

Bassler RS (1953) Bryozoa (Part G). In "Treatise on Invertebrate Paleontology" Ed by RC Moore, Geological Society of America, University of Kansas Press, Lawrence, pp 1-253

Bishop JDD, Househam BC (1987) Puellina (Bryozoa: Cheilostomata: Cribrilinidae) from British and adjacent waters. Bull Brit Mus (Nat Hist) Zool 53: 1-63

Busk G (1852) An account of the Polyzoa, and sertularian zoophytes, collected in the voyage of the Rattlesnake, on the coasts of Australia and the Louisiade Archipelago, \&c. In "Narrative of the Voyage H.M.S. Rattlesnake Commanded by the Late Captain Owen Stanley, During the Years 1846-1850 ... Vol 1" Ed by J MacGillivray, T. W. Boone, London, pp 343402

Calvet $L$ (1900) Contribution à l'histoire naturelle des Bryozoaires Ectoproctes marins. Trav Inst Zool Univ Montpellier NS 8: 1488

Canu F, Bassler RS (1927) Bryozoaires des lles Hawaï. Bull Soc Sci Seine Oise 7 (Suppl 1927): 1-67

Canu F, Bassler RS (1929) Bryozoa of the Philippine region. Bull US Natl Mus 100: I-XI, 1-685

Chimonides PJ, Cook PL (1994) Notes on the genus Cranosina (Bryozoa, Cheilostomida). Zool Scr 23: 43-49

Cook PL (1968) Polyzoa from West Africa. The Malacostega. Part I. Bull Brit Mus (Nat Hist) Zool 16: 115-160

Corrêa DD (1948) A embryologia de Bugula flabellata (J. V. Thompson) Bryozoa Ectoprocta. Bol Fac Fil Cien Let Univ São Paulo Zool 13: 7-71

Dick MH, Ross JRP (1988) Intertidal Bryozoa (Cheilostomata) of the Kodiak Vicinity, Alaska. Center for Pacific Northwest Studies Occasional Paper 23, Western Washington University, Bellingham

Dick MH, Grischenko AV, Mawatari SF (2005) Intertidal Bryozoa (Cheilostomata) of Ketchikan, Alaska. J Nat Hist 39: 3687-3784

Dyrynda PEJ, King PE (1983) Gametogenesis in placental and nonplacental ovicellate cheilostome Bryozoa. J Zool Lond 200: 471-492

Fabricius O (1780) Fauna Groenlandica. J.G. Rothe, Hafniae and Lipsiae

Gerwerzhagen A (1913) Untersuchungen an Bryozoen. Sitz Heidelberg Akad Wiss Mathemat Naturwiss Klas B 9: 1-16

Gostilovskaya MG (1978) Bryozoa of the White Sea. Nauka Press, Leningrad (in Russian)

Grischenko AV, Taylor PD, Mawatari SF (2002) A new cheilostome bryozoan with gigantic zooids from the north-west Pacific. Zool Sci 19: 1279-1289

Grischenko AV, Dick MH, Mawatari SF (2007) Diversity and taxonomy of intertidal Bryozoa (Chelostomatida) at Akkeshi Bay, Hokkaido, Japan. J Nat Hist 41: 1047-1161

Hastings AB (1945) Notes on Polyzoa (Bryozoa). II. Membranipora crassimarginata auctt., with remarks on some genera. Ann Mag Nat Hist 11 Ser 12: 69-103

Hastings AB (1964) The cheilostomatous Polyzoa Neoeuthyris woosteri (MacGillivray) and Reginella doliaris (Maplestone). Bull Brit Mus (Nat Hist) Zool 11: 243-262

Hayward PJ (1995) Antarctic Cheilostomatous Bryozoa. Oxford University Press, Oxford

Hayward PJ, Ryland JS (1979) British ascophoran bryozoans. Synopses Brit Fauna NS 14: 1-312

Hayward PJ, Ryland JS (1998) Cheilostomatous Bryozoa, Part 1. 
Aeteoidea-Cribrilinoidea. Synopses Brit Fauna NS 10 (2nd ed): 1-366

Hincks T (1873) Contributions to the history of the Polyzoa. Q J Micr Sci, NS 13: 16-36, pl 2

Hincks T (1877) On Polyzoa from Iceland and Labrador. Ann Mag Nat Hist (Ser 4) 19: 97-112, pls 10, 11

Hincks T (1880) A History of the British Marine Polyzoa Vol 1. John Van Voorst, London

Hincks T (1881) Contributions towards a general history of the marine Polyzoa. VII. Foreign Membraniporina (third series). Ann Mag Nat Hist (Ser 5) 8: 129-132, pl 3

Hincks T (1882) Polyzoa of the Queen Charlotte Islands: preliminary notice of new species. Ann Mag Nat Hist (Ser 5) 10: 248-256

Hyman LH (1959) The Invertebrates: Smaller Coelomate Groups Vol 5. McGraw-Hill, New York

ICZN (1999) International Code of Zoological Nomenclature. 4th ed, International Trust for Zoological Nomenclature 1999, London

Johnston $G$ (1832) A descriptive catalogue of the recent zoophytes found on the coast of north Durham. Trans Nat Hist Soc Newcastle 2: 239-272

Jullien J, Calvet $L$ (1903) Bryozoaires provenant des campagnes de l'Hirondelle (1886-1888). Résult Camp Sci Prince Albert I 23: $1-188$

Kluge GA (1962) Bryozoa of the northern Seas of the USSR. Opredeliteli po Faune SSSR 76: 1-584 (In Russian)

Kluge GA (1975) Bryozoa of the Northern Seas of the USSR. Amerind Publishing, New Delhi (English translation of 1962 Russian volume)

Kuklinski P, Taylor PD (2006) A new genus and some cryptic species of Arctic boreal calloporid bryozoans. J Mar Biol Assoc UK 86: $1035-1046$

Levinsen GMR (1909) Morphological and Systematic Studies on the Cheilostomatous Bryozoa. F. Bagge, Copenhagen

Mawatari S (1973) Studies on Japanese Anascan Bryozoa. 2. Division Scrupariina. Bull Nat Sci Mus Tokyo 16: 605-624

Mawatari S, Mawatari SF (1981) Studies on Japanese Anascan Bryozoa 6. Division Malacostega (4). Bull Libr Art Sci Sch Med Nihon Univ 9: 23-61

Nielsen C (1981) On morphology and reproduction of "Hippodiplosia" insculpta and Fenestrulina malusii (Bryozoa Cheilostomata). Ophelia 20: 91-125

Nitsche $H$ (1869) Beobachtungen über die Entwicklungsgeschichte einiger chilostomen Bryozoen. Z Wiss Zool 20: 1-13

Norman AM (1903) Notes on the natural history of East Finnmark. Polyzoa. Ann Mag Nat Hist (Ser 7) 11: 567-598, 12: 87-128

Osburn RC (1950) Bryozoa of the Pacific coast of America. Part 1, Cheilostomata-Anasca. Allan Hancock Pacif Exped 14: 1-269

Ostrovsky AN (1998) Comparative studies of ovicell anatomy and reproductive patterns in Cribrilina annulata and Celleporella hyalina (Bryozoa: Cheilostomatida). Acta Zool 79: 287-318

Ostrovsky AN, Schäfer P (2003) Ovicell structure in Callopora dumerili and C. lineata (Bryozoa, Cheilostomatida). Acta Zool 84: 15-24
Ostrovsky AN, Schäfer P, Gordon DP (2003) Ultrastructure and development of the ooecial walls in some calloporid bryozoans (Gymnolaemata: Cheilostomata). Zool Anz 242: 223-240

Ostrovsky AN, Grischenko AV, Taylor PD, Bock P, Mawatari SF (2006) Comparative anatomical study of internal brooding in three anascan bryozoans (Cheilostomata) and its taxonomical and evolutionary implications. J Morph 267: 739-749

Prenant M, Bobin G (1966) Bryozoaires. 2. Chilostomes Anasca. Faune France 68: 1-647

Reed CG (1991) Bryozoa. In "Reproduction of Marine Invertebrates Vol 6. Echinoderms and Lophophorates" Ed by AC Giese, JS Pearse, VB Pearse, Boxwood Press, Pacific Grove, pp 85-245

Richardson KC, Jarrett L, Finke EH (1960) Embedding in epoxy resins for ultrathin sectioning in electron microscopy. Stain Technol 35: 313-323

Ryland JS (1976) Physiology and ecology of marine bryozoans. In "Advances in Marine Biology Vol 14" Ed by FS Russell, CM Yonge, Academic Press, London, pp 285-443

Ryland JS, Hayward PJ (1977) British anascan bryozoans. Synopses Brit Fauna NS 10: 1-188

Seo JE (2001) A new species of the genus Cauloramphus (Bryozoa, Cheilostomata) from Korea. Kor J Syst Zool 17: 223-228

Seo JE (2005) Illustrated Encyclopedia of the Fauna \& Flora of Korea. Vol 40, Bryozoa. Ministry of Education, Daehan Printing \& Publishing Company, Seoul

Silén $L$ (1945) The main features of the development of the ovum, embryo and ooecium in the ooecioferous Bryozoa Gymnolaemata. Ark Zool 35A: 1-34

Silén L (1977) Polymorphism. In "Biology of Bryozoans" Ed by RM Woollacott, RL Zimmer, Academic Press, New York, pp 184232

Soule DF, Soule JD, Chaney HW (1995) Taxonomic atlas of the benthic fauna of the Santa Maria Basin and western Santa Barbara Channel. Irene McCulloch Fdn Mon Ser 2: 1-344

Taylor PD (1988) Major radiation of cheilostome bryozoans: triggered by the evolution of a new larval type. Hist Biol 1: 45-64

Tilbrook KJ, Hayward PJ, Gordon DP (2001) Cheilostomatous Bryozoa from Vanuatu. Zool J Linn Soc 131: 35-109

Vigelius WJ (1884a) Die Bryozoen, gesammelt während der dritten und vierten Polarfahrt des "Willem Barents" in den Jahren 1880 und 1881. Bijdr Dierk 11: 1-104

Vigelius WJ (1884b) Morphologische Untersuchungen über Flustra membranaceo-truncata Smith. Biol Zentralb 3: 705-721

Winston JE (1984) Shallow-water bryozoans of Carrie Bow Cay, Belize. Am Mus Novit 2799: 1-38

Winston JE, Håkansson E (1986) The interstitial bryozoan fauna from Capron Shoal, Florida. Am Mus Novit 2865: 1-50

Woollacott RM, Zimmer RL (1972) Origin and structure of the brood chamber in Bugula neritina (Bryozoa). Mar Biol 16: 165-170

(Received February 16, 2007 / Accepted August 18, 2007) 